\title{
MODEL MANAGEMENT TRAINING OF CLASSROOM ACTION RESEARCH BASED ON ISLAMIC MODERATE FOR ISLAMIC EDUCATION
}

\author{
Nur Cholid', Masrukhi', Rusdarti ${ }^{3}$, AT Sugito ${ }^{4}$ \\ 1) Universitas Wahid Hasyim Semarang; ${ }^{2,3,4}$ ) Universitas Negeri Semarang \\ e-mail:nurcholid@unwahas.ac.id
}

\begin{abstract}
Efforts which done to increase teacher's quality such as giving training about curriculum, learning method, and continuing study for those who have not under-graduate program yet. But those efforts seem did not work well maximally to increase process quality and learning result. For those reason, Action Research training is needed to increase profesional competence of Islamic Education teacher. This research was conducted with the aim to produce a product, that is the management model of Classroom Action Research based on Islamic moderate for Islamic Education Teachers, which will be packaged in the form of a manual of classroom action research training model for Islamic education teachers handbook. This study used the Research Development (Research and Development) approach, which was preceded by qualitative descriptive method as the first step in this research. The results showed that the development of the classroom action management training model was carried out in accordance with the development procedure, which included preliminary research, analysis, production / development, and revision, while evaluation of the product was developed in accordance with the development evaluation procedure.
\end{abstract}

Keywords: model of training management; Classroom Action

Research (PTK); Islamic moderate

Tawasut - ISSN 2338-042X - Vol 5, No 1 (2017) 


\section{ملخص البحث}

تمت محاولات لترقية نوعية المدرسين في المدارس، مثل إثراكهم في الدورة الثدريبية

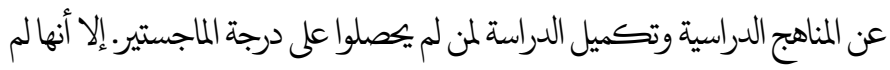
تكن على نتيجة مأمولة، ما تتطلب إلى عقد دورة تدريبية عن بحث ميداني في عملية التدريس في الفصول المبنية على تعاليم الإسلام الوسطي لمدرسي التربية الإسلامية.

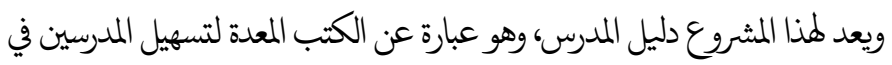
عمليتهم التدريسية.

يستعمل هذا البحث منهج البحث والتنمية بطريقة وصفية نوعية.وتوصل إلى نتيجة أن تنمية نموذج إدارة الدورة الثدريبية عن بحث ميداني في عملية الثدريس في الفصول تمت على منوال عملية التنمية التي تتضمن على البحث الأولي، تحليل التنمية، والثنقيح، مع أن تقييم المنتج تم تطويرووفق عملية تقييم التنمية.

الكلمات المفتاحية : نموذج إدراة الدورة الثدريبية، بحث ميداني في عملية التدريس في الفصول، الإسلام الوسطي 


\section{Introduction}

Educators are professionals who must have minimum qualifications and certification in accordance with the level of teaching authority, physically and mentally healthy and have the ability to realize the goals of national education, as specifically set out in Law Number 20 Year 2003 on National Education System that gave birth to a new paradigm National Education. In addition, PP No 19 th 2005 on SNP, requires educators to have academic qualifications and competence as a learning agent, physically and mentally healthy, and have the ability to realize the goals of national education. This demand suggests taking seriously the critical use of science.

In other words, Teachers are expected to have knowledge and understanding about good teacher profession, so that they become teacher figure with character and professionalism. Thus, Roche's (1989) view that "I've never seen a good school without a good teacher" can come true. In fact, from various studies, until now, the quality of teachers is suspected to be still less satisfactory, both in terms of mastering the substance of science and competence in organizing learning that educate. Mastery of subject matter is considered less profound. In addition, his competence in organizing educational learning is more theoretical. The issue of low teacher quality can not be separated from the almost inevitable global challenges and national situation changes. Both of these factors have implications for the need to improve the quality standards of teachers to reach or close to national and international standards, so as to produce qualified graduates and have a strong character.

Several attempts have been made to improve the quality of teachers, such as providing training on learning methods, curriculum, and advanced studies for those who have not been under-graduate, but those efforts do not seem to be maximally successful in improving the quality of the learning process and outcomes. This is caused by the habit of the teachers when they have completed the training is 'back to their habit' (the result of informal interview with the supervisor of Islamic Religious Education School (PAIS) in Semarang City). Teachers return by teaching the old ones so that the training that has been given is useless because the knowledge gained is not applied in school.

Tawasut - ISSN 2338-042X - Vol 5, No 1 (2017) 
Based on the habits, then change the training materials that is to provide classroom action research training to the teacher, through this training, the teacher is given the opportunity to reflect on the learning that has been done, so that teachers are aware of mistakes and problems that occur and also consciously they find a solution to their own problems.

According Joni (1998), the ability to conduct Classroom Action Research is a representation of professional competence and paedagogik holistically that can improve the quality of student learning process and result which is one of the characteristics of teacher professionalism, it is same with Arash Shahin and Samea (2010: 213) ${ }^{1}$, in Developing the Models of Service Quality Gaps: A Critical Discussion, Haslinda. A (2009) ${ }^{2}$, in The Effectiveness of Training in the Public Service. And Hairul Ismail (2009: 216) ${ }^{3}$, in Competency Based Teacher Education (CBTE): A Training Module for Improving Knowledge Competencies for Resource Room Teachers in Jordan, describing training can measure the effects of training modules in enhancing knowledge competence.

In addition, some scholars define the meaning of similar classroom action research such as John Elliot: Classroom action research is a study of social situations with a view to improving the quality of actions in which the process has undergone a review, diagnosis, planning, implementation, monitoring and evaluation, Kemmis and McTaggart: Classroom action research is a form of collective reflection by participants in social situations to improve the reasoning and fairness of these practices against the situations in which they are practiced, Siswoyo Harjodipuro: Classroom action research is an approach to improving education through change encouraging teachers to think about their own teaching practices.4 Classroom Action Research is an action research conducted by a teacher who simultaneously as a researcher in

\footnotetext{
1Shahin A \& Samea, M. “Developing the models of service quality gaps: A Critical Discussion”. Jurnal Macrothink Institute. Business Management and Strategy. 1 (1): E2.2010. P. 213

${ }^{2}$ Haslinda., The Effectiveness of Training in the Public Service. American Journal of Scientific Research. 2009.p.39-51

3 Hairul, Nizam Ismail. Competency Based Teacher Education (CBTE): A Training Module for Improving Knowledge Competencies for Resource Room Teachers in Jordan. European Journal of Social Sciences. 2009, Volume 10. Number 2.

${ }^{4}$ Kunandar. Langkah Mudah Penelitian Tindakan Kelas Sebagai Pengembangan Profesi Guru. Jakarta: PT. RajaGrafindo Persada, 2013. P.48
} 
his class or together with others by designing, implementing and reflecting collaborative and participatory actions aimed at improving or improving the quality of the learning process in his classroom with a certain actions in a cycle. In classroom action research there are three elements or concepts, namely research, action and class. Later in the study incorporating a moderate moderate Islamic Classroom Action Research, moderate Islam means a middle or moderate attitude that does not tend to the right or the left.5 In the context of nation and state and in other fields, moderate thought is very urgent to be passionate in accommodating diverse interests and disputes, and then seek the best possible solution, in Q.S. al-Baqarah: 143 God speaks.



Thus, have We made of you an Ummat justly balanced, that ye might be witnesses over the nations, and the Messenger a witness over yourselves (QS alBaqarah: 143). ${ }^{6}$

From the above verse explains that Rasululloh saw as a measure of Muslims while Muslims become a measure for humans in general so Tawassuth are people who have a method of religious thinking that covers all aspects of life based on the basics of moderation, maintaining balance, and tolerance where This Ahlussunnah Waljamaah should be placed proportionally, ie Ahlussunnah Waljamaah not as a school, but only a manhaj al-fikr (certain way of thinking) that has high intellectuality and relatively neutral in addressing the situation. However, it does not mean that Ahlussunnah Walj amaah as manhaj al-fikr is a product free from the sociocultural and socio-political realities that surround it.

On the other hand, the result of the interview with the head of the Teachers' Meeting of Islamic Senior High School (MGMP-PAI SMA) for

\footnotetext{
${ }^{5}$ Said Aqil Siradj, Ahlussunnah waljamaah dalam Lintas Sejarah, (Yogyakarta: LKPSM, 1999), p. 35.

${ }^{6}$ Departemen Agama Republik Indonesia, Al Qura'an dan terjemahannya, (Semarang; Assyifa, 2003), p. 135.
}

Tawasut - ISSN 2338-042X - Vol 5, No 1 (2017) 
Semarang city, supervisory group (POKJAWAS), PAIS, and teachers who had attended the training found that in the training given, less teachers were given the opportunity to study systematic and controllable about the various learning problems faced in everyday life. Teachers were poorly trained on how to diagnose their own learning problems, find out the main causes of the problem, and conduct systematic, controlled, and programmed learning therapies on an ongoing basis. In other words, less teachers are given the opportunity to reflect on their own learning. The training model as above is a traditional training model whose stages were the instructor transferring knowledge about classroom action research to the participants, and then the practice of preparing classroom action research proposal. Such as models have not been able to fully train teachers' reflective skills and competence to plan Classroom Action Research to improve the quality of their learning.

By looking at the weakness of the training that has been done, it is necessary to develop a classroom action reserarch classroom management model that gives teachers the opportunity to practice reflecting on the implementation of their own KBM. The absence of a training model that can combine the provision of knowledge of PTK (received knowledge) and empirical knowledge (previous experiential knowledge) that is the real problem faced in the classroom; to support reflective capabilities, a model of training that is capable of providing real-time experience and not only emphasizes theoretical aspect but also provides the opportunity for teachers to have applicative competencies that will be able to form competent and professional teachers. Training activities should be structured on the basis of appropriate training activities in accordance with the theory, which includes planning, implementation, and evaluation either in the form of products or test results, and follow-up.

Based on the above background it is necessary to develop a way of solving the problem that is how to develop a model management training Classroom Islamic Action-Based Research for teachers of Islamic High School Education, The purpose of this study (1) Analyze the factual model of management training for teachers Islamic high school education in the city of Semarang that has been running for this; (2) Designing hypothetical model management training Research Action Class moderate Islamic-based for teachers Islamic 
high school education in Semarang City based on professional competence; (3) Describe the final model and effectiveness of the developed training management model, is moderate Islamic class-based action research training for Islamic High School Islamic Education Teachers in Moderate Moderatebased Semarang City that can develop professional competence. While the Research Benefits Theoretically, the research results will contribute knowledge and insight for the development of science especially related to the development of management model of moderate Islamic class-based action research training to improve professional competence for Islamic Religious Education Teachers.

\section{Research Method}

Research method used is research and development model (Research And Development) Borg \& Gall (2007: 590). ${ }^{7}$ Stages in this study include (1) preliminary study stage and model design, (2) model development stage, and (3) model validation stage. (Sukmadinata, 2006: 179). Techniques of collecting research data was using interviews, documentation, obeservasi, questionnaire and pre test results and Post test. Validity of data is done with reliability, validity, while data analysis technique used interactive model, qualitative, quantitative, and experiment. Model validation was done by experts / practitioners. Model trials were conducted with limited trials of 15 teachers and an extended trial of 35 teachers from various senior high school PAI teachers in Semarang City. In detail the stages of research and development design are presented in the opinion of Borg \& Gall (2007: 590); ${ }^{8}$ a) Preliminary of Study Stages; This stage was carried out by reviewing the literature, field studies and describing and analyzing the findings / models that are currently underway. There are also activities conducted among others; (1) analyzing the training management model which includes planning, organizing, implementing, and evaluating that have been done for teachers of Islamic Education and its equipment; (2) to analyze the content of curriculum of Islamic education subject; (3) analyze sub-subject matter; and (4) direct review in the field to

\footnotetext{
${ }^{7}$ Borg Walter R., Gall, Meredith D, dan Gall, Joyce P.. Educational Research : An Introduction, Eighth Edition. (New York: Logman, 2007), p. 590.

${ }^{8}$ Ibid, p. 591 .
}

Tawasut - ISSN 2338-042X - Vol 5, No 1 (2017) 
observe the training implementation documents and discuss with practitioners to explore information and constraints faced to find alternative solutions; and (5) describe and simultaneously analyze model findings. b) Development Stage; This development stage was carried out by the activities covering (1) Preparation of the design for classroom action research training model based on the professional competence improvement of Islamic education teachers; (2) Preparation of Training Tools; (3) Focussed Group Diccusion (FGD); (4) Consultation of experts and practitioners; (5) Model Revisions; (6) Preparation of Hypothetical Model; (7) The trial is limited, and the trial is expanded. The subjects of the trial in this study were 15 teachers as subjects of limited trials and 35 teachers as the subjects of the trial were expanded. Technique of data collection and Types of data consist for quantitative data and qualitative data. This research was preceded by qualitative descriptive method as the first step in this research. Qualitative descriptive method was conducted as a preliminary study to obtain data on how the implementation of education and training that has been running for this. Through preliminary studies could find out what the problems in the implementation of education and training that has been running it. In addition to data about the problem, researchers will also know what the potential of the research subject. c) Validation Stage; The validation model of training management for classroom action research based on the improvement of professional competence for Islamic education teachers of senior High School in Semarang City, it was conducted by using one group pretest-posttest design experimental design (Borg \& Gall, 2007). The purpose of this design was to test the effectiveness of the model and the validation of conceptual models that have been generated empirically. Testing the effectiveness of the model is done on the conceptual model developed so it can be an empirical model or feasible applied. Model training validation is carried out after the trial is limited or expanded. The test results are used to revise and validate the developed training model. The design of validation and model evaluation using "the one shot case study" or evaluation process in this research is emphasized on the assessment of training model that aims to (a) compare the competency level of participants before and after training so that it can be seen whether the training model is more efficient in implementation of training, and (b) knowing what participants have mastered and which competencies have not been mastered by the participants. 
Technique of data analysis used were (1) technique analysis of descriptive data, and (2) statistical analysis techniques. It was to describe the research data obtained from the questionnaire instrument filled by the respondent The criteria of the quantitative description consist of four namely: very good $(3,28-4,00)$, good $(2,52-3,27)$, unfavorable $(1,76-2,51)$, and not good $(0,00$ 1,75). The effectiveness test to find out the effectiveness model of training management final findings of for classroom action research has been able to improve the professional competence of teachers of Islamic Senior High School in accordance with the criteria of minimum completeness (KKM) which has been established is 75 . Thus the participants who have scores $<75$ belong to the category are classified yet competent.

And for descriptive analysis technique, the researcher directs to the understanding and appraisal of meaning according to what the subjects constructed under their social interaction, and not according to the researcher's formulation (Imam G., 2009). ${ }^{9}$ Qualitative research there are several ways to test the validity or validity of data. There are four criteria for measuring of validity data, namely: credibility, transferability, dependability, and confirmability, (Moleong L.J., 2007). ${ }^{10}$

\section{Result and Discussion}

\section{Results of Training Needs Assessment}

Table 1.1 Average Score Aspects of Training Needs of CAR

\begin{tabular}{|c|l|c|c|c|}
\hline NO & $\begin{array}{c}\text { The element of need } \\
\text { assessed }\end{array}$ & average & score & Criteria \\
\hline 1. & Training material & 3,66 & 4 & Very good \\
\hline 2. & Instructor competence & 3,74 & 4 & Very good \\
\hline 3. & Training management & 3,71 & 4 & Very good \\
\hline Score average & $\mathbf{3 , 7 1}$ & $\mathbf{4}$ & Very good \\
\hline
\end{tabular}

Source: research data (processed 2016)

\footnotetext{
${ }^{9}$ Imam, G. Aplikasi Analisis Multivariate Dengan Program SPSS. Edisi Keempat. (Semarang; Penerbit Universitas Diponegoro, 2009).p. 31.

${ }^{10}$ Moleong, L.J. Metodologi Penelitian Kualitatif.(Bandung; Remaja Rosda Karya. 2007), p.59.
} 
Based on Table 1.1 it can be seen that the need for classroom action research training as a whole shows that the level of need for classroom action research training with average score of 3.71 was very high. This level of need was a reflection of the overall need for classroom action research training on Islamic education teachers of senior high school in Semarang City. Development in formal teaching and learning should be embedded in the curriculum objectives, outcomes and teaching strategies of the learning program (Adnan et al., 2012). The description was in accordance with the opinion of Eugene \& Mckenna (2000), Sutrisno (2009), Nawawi (1997) that training was needed to support competence, help master knowledge, skills, and develop attitudes to project positive energy on the perspective of quality performance that will give birth loyalty to work. The above findings, in line with Edmons' research (1994: 57) ${ }^{11}$ hat the concept of a training system approach can be characterized in the input-process-output paradigm, the components included in the input are Needs analysis includes (1) training materials (2) HR (participants and instructors), (3) training programs, (4) infrastructure and training media, 5) training management. The components covered in the process are the activities of the training management functions that include the design of training model design, model development, training and bimibingan implementation, evaluation and follow up. While the components included in the Output was the achievement of the competence that has been established in the form of product of the research proposal report.

The above results were in accordance with Amaliyyah research (2013: $6)^{12}$ that research as a training management system can be seen with inputprocess-output approach. As inputs the determination of training needs include potential participants, faculty, administrators, funds, facilities, infrastructure, curriculum, library books, laboratories and learning tools both hardware and software. The process includes managing the Training, managing the training program, managing the teaching and learning activities

\footnotetext{
${ }^{11}$ Edmons, G.S., Robert.., Branch, dan Prachee, M. (1994). "A Conceptual Framework for Comparing Instructional Design Models", Journal ETR \& D, Vol. 42, No. 4, 1994, pp.55-72.

${ }^{12}$ Amaliyyah. "Tinjauan Penyelenggaraan Diklat dari Aspek Input-Proses-Output di Balai Latihan Pertanian. Bandung; Widya Iswara Dinas Pertanian Jawa Barat.". 2013. p. 6.
} 
using various methods. The output is graduates whose work competence is progressing according to the standard of progress expected so as to produce the product set. Thus the quality of training is highly dependent on the effectiveness of the system, whereas the running of the system is largely determined by the professionalism of the various parties involved in the training system..

The classroom action research training for senior high school teachers of senior high school was designed to improve the ability and skill in writing of scientific work for CAR, so that prior to the implementation of the training, needs analysis, training planning, implementation and evaluation are needed. This is in the opinion of Notoatmodjo (2009: 19: 23) ${ }^{13}$ that the training process consists of several stages, namely: (1) the determination stage of needs, (2) hold implementation, and (3) evaluation phase.

\section{The study result of training development model}

Table 1.2 Expert Assessment of CAR Training Model

\begin{tabular}{|c|l|c|}
\hline No & \multicolumn{1}{|c|}{ Aspect } & Score average \\
\hline 1 & Rational model & 4,00 \\
\hline 2 & Assumption Model & 4,00 \\
\hline 3 & Stages of Management Functions & 3,67 \\
\hline 4 & Instructor Task & 3,92 \\
\hline 5 & Participants Task & 3,67 \\
\hline 6 & Implementation Model & 4,00 \\
\hline 7 & Visualization of drawing Model & 3,75 \\
\hline \multicolumn{2}{|c|}{ Average } & 3,86 \\
\hline
\end{tabular}

Source: research data (processed 2016)

The assessment of the expert team on the overall classroom action research training model shows that the assessment level is very good with an average score of 3.86. This level of assessment is an overall reflection of the assessment of the form of classroom action research training that can be used in training for senior high school of Islamic education teachers.

\footnotetext{
${ }^{13}$ Notoatmodjo, Pengembangan Sumber Daya Manusia. (Jakarta: Rineka Cipta, 2003), p. 19-23.

Tawasut - ISSN 2338-042X - Vol 5, No 1 (2017)
} 
The assessment result of expert team to form of research training management model of CAR, in accordance with the research results Iswara (2005), ${ }^{14}$ that training can improve knowledge of management functions, increase commitment to the profession, and improve skills. This is in accordance with the expert team's assessment of the classroom action research training model, so it can be used as a training management model that has a very high effectiveness value because it is easy to implement.

This was in accordance with the opinion of Saondi and Suherman (2010: 71-82 $)^{15}$ that teacher training and development was one of the important factors in human resource development in education, not only increase knowledge, but also improve work skills. Thus improving work productivity, teacher professional development had a functional relationship and influence on teacher performance, because it strengthens the professional ability of teachers in carrying out the work. So that the result of expert / practitioner assessment and practitioner toCAR training model can be used as the hypothetical model of training model to be final model that has a very high feasibility value because it is easy to understand especially on the implementation of training.

Thus, based on the data above, it can be said that the holding of CAR training for Islamic education teachers of senior high school in Semarang City will be very useful, for education in general, for schools and for trainees. Training of CAR for Islamic education teachers of senior high school was a final training model of the outcome of the development process in an effort to improve the knowledge, skills, attitudes and ability of teachers in writing scientific papers as part of the teacher's obligations in the development of sustainable profession.

The following is presented a final model of classroom action research (CAR) training for Islamic education teachers of senior high school in Semarang City. Figure. 1

\footnotetext{
${ }^{14}$ Iswara. Hubungan antara fungsi Manajemen komitmen terhadap profesi, ketrampilan, manajerial staf dengan efektivitas penyelenggaraan Pendidikan dan Pelatihan pada Pusat Pendidikan dan Pelatihan Kejaksaan Agung Republik Indonesia. Tesis, (Jakarta; Pascasarjana Universitas Negeri Jakarta. 2005), p. 45 .

${ }^{15}$ Saondi, \& Suherman. Etika Profesi Keguruan (Bandung: Refika Aditama. 2010), p. 71-82.
} 
Model Management Training of Classroom Action Research ....



Figure 1 The Final Model of Classroom Action Research Training

Tawasut - ISSN 2338-042X - Vol 5, No 1 (2017) 
The final model of CAR training based on moderate Islamic for Islamic education teacher of SHS to improve their professional competence. The final model of CAR training was carried out by keeping in mind the stages of the ADDIE and In-On-In modes packaged in the IPO (input-process-output).

In the input stage includes the analysis phase, the analysis phase was a process of defining what will be studied by the trainee, that is doing need assesmnet (needs analysis), identifying problem (requirement), and doing task analyst (Task analysis). Therefore we will produce was a characteristic or profile of prospective trainees, gap identification, needs identification and detailed task identification based on needs. Needs analysis includes (1) training materials (2) human resources (participants and instructors), (3) training programs, (4) training facilities and media, 5) training and 6) training costs.

At the stage of the process or process management includes the design stages of training model design, model development, training implementation and training evaluation. Stage Design model, was the design phase of the training model design include: Design of training program planning, training implementation design and training evaluation design. The stage of model development is the preparation and development of terms of reference (TOR) of training devices / instruments, and trials. Preparation and development of terms of reference (TOR) of training instruments / instruments including; (1) training manuals, (2) training materials booklets by incorporating moderate Islam (3) training manuals for participants and instructors and (4) research instruments. The implementation phase of the training, the implementation of the training is based on the needs analysis, training objectives, the design of training programs, and the implementation of the training conducted according to the strategy and scenario of the training process. The evaluation phase of the training, at this stage is the assessment of the implementation of the training program which includes assessment of the training model, training program, and attitude assessment of the trainees so that continuous observation was required during the training activities to measure the improvement of cognitive, affective and psychomotor competence, to participants, the participants 'opinions contained in the evaluation of platinum program, the evaluation of the participants' attitude and the evaluation of the training model which contains the elements of how to 
design the model, whether there are benefits, practicality and feasibility of the training model. The follow-up training program was an activity to review and reflect the activities of the training activities. Follow-up activities were prepared by taking into account the criticism and suggestions of the participants during the course of the training activities.

Output stages are the stages of the training result that was the achievement of the objectives of the competence that has been established in the form of product report of the result of research proposal of class action. Thus the quality of training was very dependent on the effectiveness of the system, whereas the running of the system was determined by the professionalism of the various parties involved in the training system.

\section{Handbook of Training Management Model}

The Handbook of classroom action research training was an instruction manual containing training and training management models. Handbook of the classroom action research training model developed entitled "Classroom Action Research Training Class Guide" The contents of this Handbook include: (1) Introduction, including sub-headings: rationalization, legal basis, objectives, objectives and expected results; (2) Implementation of the training, covering subtitles of participants, time and place, resource persons / instructors, committees, PTK training activities scenarios, program structure, training methods, training schedule, financing and evaluation: (3) participant roles, participant duties, and participant rights, instructor order, instructor duties and instructor rights: and (4) cover.

Generally, based on the results of the evaluation with the Education Management Expert, the Islamic education Expert, and the Training Expert, indicated that the CAR Training Handbook is conceptually good and deserves to be used as a guide or guideline for conducting classroom action research for Islamic education teacher of SHS. This Handbook is one of the most important training tools for training implementation as a guide for conducting training to achieve the objectives of training the CAR is achieved The use of this training manual will greatly assist the implementation of training in understanding the nature of classroom action research training. 


\section{Training Material Book}

The training material book is a training package that guides trainees in making it easy to absorb training / learning materials. This material book can be used as a source of CAR training materials. In accordance with the types and approaches of developing TODs, the content of this material book contains: (1) introduction covering the subject title: TOD for Islamic Religious Education teachers, general competence and instructional guidance, (2) training on the nature of PTK covering special introduction, material, summary, and follow-up. (3) Closing.

Table 1.3 the result of expert assessment score on CAR material book

\begin{tabular}{|c|l|c|c|}
\hline NO & \multicolumn{1}{|c|}{ Aspect } & Average & Criteria \\
\hline 1 & $\begin{array}{l}\text { The material conformity to the } \\
\text { needs of trainees }\end{array}$ & 4,00 & Very good \\
\hline 2 & Systematic training material & 3,25 & Very good \\
\hline 3 & $\begin{array}{l}\text { The relevance of material to the } \\
\text { needs of students in the future }\end{array}$ & 4,00 & Very good \\
\hline 4 & $\begin{array}{l}\text { Completeness of material } \\
\text { support }\end{array}$ & 3,75 & Very good \\
\hline 5 & Level of material readability & 3,75 & Very good \\
\hline & Average & 3,75 & Very good \\
\hline
\end{tabular}

Source: Research Data (processed 2016)

Based on the result of the assessment by the expert / expert / experiment shows that the training material product is conceptually good and suitable for the training participants as the classroom action research training material, although there are some things that need to be improved as input and suggestion. Revisions are made: (1) some additional concrete examples, ranging from problem formulation, benefits, research objectives and research titles, (2) some writings and spelling letters, (3) design of books arranged better cover and color. The module book of the assessed training materials is considered well because as one of the learning sources is very supportive of the training process. The module book of content training materials has been in line with the essence of the training materials of PTK training. This is in Soemarman's opinion (2010: 45) that the principle of learning that 
emphasizes the importance of the process and the availability of adequate teaching materials according to need. 1

This is in accordance with the opinion of Olofsson \& Lindberg (2006), ${ }^{2}$ that teacher training has a positive effect on the quality of the training peseta, both individually and socially. The same thing was found by Soemarman (2010), who stated that the training module is a teaching material that is compiled as a whole and systematically in the form of a script that takes into account: (l) the module must contain complete information; (2) the module helps the trainee understand the training materials, learn them, and complete the task or practice of the exam demanded by the module itself; (3) the contents of the module are divided into fragments according to their subtopics; (4) modules prepared based on outline of learning content and training planning with reference to syllabus, competency standard, and basic competence.

\section{The Study of Participant's Assessment on Training Model}

Table 4.4 the assessment of participants to CAR training model (Limited and test expanded)

\begin{tabular}{|c|c|c|c|c|c|}
\hline \multirow{2}{*}{ NO } & \multirow{2}{*}{ Aspect of assessment } & \multicolumn{3}{|c|}{ Average of score } & \multirow{2}{*}{ Category } \\
\cline { 3 - 5 } & & (UcT) & (UcD) & Total & \\
\hline 1 & Material of training & 3,25 & 3,52 & 3,38 & Very good \\
\hline 2 & Instructor competence & 3,27 & 3,59 & 3,43 & Very good \\
\hline 3 & Management & 3,47 & 3,54 & 3,50 & Very good \\
\hline \multicolumn{2}{|c|}{ Average score } & 3,33 & 3,55 & 3,44 & Very good \\
\hline
\end{tabular}

Source: Research Data (Processed 2016)

In the implementation of the classroom action research management model, from limited and expanded trials showed that this classroom action management training classroom development model is more easily understood and implemented by Islamic education teacher of SHS. Implementation

\footnotetext{
${ }^{1}$ Soemarman, T. Maximizing Training. (Malang; Diamo, 2010). P. 45

${ }^{2}$ Olofsson \& Lindberg. Whatever Happened do The Social Dimension Aspect of learning in a Distance-based Teacher, 2006, p.124.
}

Tawasut - ISSN 2338-042X - Vol 5, No 1 (2017) 
of this training model provides real experience to training organizers (MGMP) and trainees (Islamic education teacher of SHS) in understanding classroom action research training materials. The above description is in line with Simamora's (2006) opinion, which states that training was a series of activities designed to increase skills, knowledge, and experiences that lead to a change of attitude. Training was directed to help trainees improve their competence. This classroom action research training was also a series of wellmanaged activities to help Islamic education teacher of SHS improve their knowledge, provide experience in making scientific work, bring positive attitude change, and uplift the spirit and research spirit that leads to the improvement of teacher competence.

\section{The Result Study of Final Development}

The CAR training model development was a training model that aims to enable participants to develop their knowledge and skills to implement CAR starting from making the formulation of title till the process of proposal writing. In contrast to the model of Semarang city used, here the use of training model was still conventional, the material of training has not focused on scientific material of CAR, but it was a part of another training subject, the determination of participants' training with direct appointment, the prepared instructor does not match with the heterogeneity of participant, not support with standard training tool, the guide book was still common implementation, the contains only take schedule and training material. While participant and instructor guide books do not exist. The material module was only a power point handout from instructor. The evaluation of training program was not about only evaluation to participant, evaluation to instructor, impression of participant to training follows, and short training time, therefore this research had minimum of product. Whereas at the CAR training model of development result had been beneficial for Islamic studies teacher of senior high school, the training material had focused on scientific writing of CAR, the participant was originally from Islamic studies teacher of senior high school of Semarang, there was a main instructor, the implementation had been equipped with training devices, guide book for training, the module book of material training and syllabus contained in the book of training device and during do a training 
the evaluation was done overall. All this time, the training model was a simple model, however Model pelatihan selama ini merupakan model sederhana, tetapi the fulfillment of minimum elements to be able to organize training, therefore the development of a training model adopted in stage of ADDIE model and In-On-In which has been packaged within IPO mindset. The training model of CAR was especially designed for Islamic studies teacher, so that it was having the characteristic of Islamic studies, as well as teacher, participant, and instructor element. The purpose of training model was to draw closer of Islamic studies teacher competence of senior high school as participant with competence to be learnt, so training participant will not get asymmetry and trouble in learning material which was given. The training model of CAR has been tested and proven which produced the product of CAR proposal such as scientific writing

\section{Conclusion}

Based on the description above then thwasresearch can be summarized as follows: (1) Factual Model Management Training Classroom action research for PAI high school teachers in training activities supported by sufficient planning, among others by determining the objectives of training ie improving teacher competence and professionalism teacher PAI, supported by training programs in the form of guidelines and modules of training materials, but the guidelines are still general while the material modules have not been standard, because the appearance of handouts Power point presentations made by instructors, guide books for participants and instructors do not exist. The training implementation activities are supported by expert practitioners' instructors consisting of core teachers, lecturers, supervisors, participants not yet sufficient competence to conduct classroom action research, training materials are still general, infrastructure and training media used are sufficient. Evaluation activities of training activities are conducted in the form of assessment to participants, instructors and to the participants' satisfaction on training activities; (2) Hypotetic Model Management Classroom Action Research Training for High School PAI Teachers based on expert expertise and practitioners' validation results and FGD-1 expert practitioners and peer apperception appropriate for use in 
training pilot activities. Thwasshows the validation of the model with a very good 3.41 average, the result of device validation with the average of 61.73 wasvery good, the instrument validation result with 3.59 average wasvery good. Implementation of the training wascharacterized by a profession in the field of Islamic religious education and implemented in accordance with the strategies and scenarios that have been designed. While the evaluation activities carried out assessment of the implementation of training that includes assessment of training models, training programs, and assessment of attitudes of trainees; (3) The Final Model of Classroom Action Research Training for PAI Teachers wasproven to be appropriate for PAI teachers to improve their professionalism. Thwaswasevident from the training participants' responses to the training model as indicated by the use of the training model with a cumulative average of 3.59 (very high), there waspractically the use of training model with a cumulative average of 3.56 (very high), there wasa feasibility of the training model in training with a cumulative average of 3.55 (very high) and training activities can produce products in the form of class action research proposals; (4) The Effectiveness of Final Model Management Management Classroom Action Research Training for PAI Teachers wasvery effective to improve the competence of teachers of Religious High School Education. Thwaswasshown from the results of pre test and post test where $t$ arithmetic greater than $t$ table or $23.886>2.05$ at the level of significance 0.005 .

\section{Bibliography}

Amaliyyah. “Tinjauan Penyelenggaraan Diklat dari Aspek Input-Proses-Output di Balai Latihan Pertanian". Bandung; Widya Iswara Dinas Pertanian Jawa Barat". 2013.

Borg Walter R, Gall, Meredith D, dan Gall, Joyce P. Educational Research : An Introduction, Eighth Edition. New York: Logman, 2007.

Bridges, D. The character of discussion: A focus on students. In W. Willen (Ed.) Teaching and learning through discussion. Norwood, NJ: Ablex, 1990. 
Departemen Agama Republik Indonesia, al-Qur'an dan Terjemahannya, Semarang: Assyifa, 2003.

Edmons, G.S., Robert.C., Branch, dan Prachee, M., A Conceptual Framework for Comparing Instructional Design Models, (1994:57), Journal ETR \& D, Vol. 42, No. 4, 1994, pp.55-72. http://edutechwiki.unige.ch/en/Instructional_desaign_method.

Faisal Talib. "Pareto Analysis of Total Quality Management Factors Critical to Success for Service Industries". International Journal for Quality research. UDK- 005.6. Original Scientific Paper, 2010, (1.01). 4(2) PP.4-10.

Gede, Agung A. "Pengembangan Kompetensi Guru dalam Upaya Meningkatkan Kemampuan Profesionalismenya." Jurnal Pendidikan dan Pengajaran, Undiksha, Singaraja Bali. Edisi Khusus TH.XXXXI.2008. Mei 4-10.

Hairul, Nizam Ismail. Competency Based Teacher Education (CBTE): A Training Module for Improving Knowledge Competencies for Resource Room Teachers in Jordan. European Journal of Social Sciences. 2009, Volume 10. Number 2.

Haslinda. A. "The Effectiveness of Training in the Public Service." American Journal of Scientific Research. 39-51 (C) EuroJournals Publishing. Inc. 2009. http://www.eurojournals.com/ajsr.htm.

Heinze A \& Reiss. K. "Mistake-handling activities in the mathematics classroom: Effects of An In-Service Teacher Training On Students' Performance In Geometry". In Woo, J. H., Lew, H. C., Park, K. S. \& Seo, D. Y. (Eds.). Proceedings of the 31st Conference of the International Group for the Psychology of Mathematics Education, 3, 2007. pp. 9-16.

Imam, G. Aplikasi Analisis Multivariate Dengan Program SPSS. Edisi Keempat. Semarang; Penerbit Universitas Diponegoro. 2009

Iswara. Hubungan antara fungsi Manajemen komitmen terhadap profesi, ketrampilan, manajerial staf dengan efektivitas penyelenggaraan Pendidikan dan Pelatihan pada Pusat Pendidikan dan Pelatihan Kejaksaan Agung Republik Indonesia. Tesis, Jakarta; Pascasarjana Universitas Negeri Jakarta. 2005

Kunandar. Langkah Mudah Penelitian Tindakan Kelas Sebagai Pengembangan Profesi Guru. Jakarta: RajaGrafindo Persada, 2013. 
Moleong, L.J. Metodologi Penelitian Kualitatif. Bandung: Remaja Rosda Karya. 2007

Muchit muzadi,, NU dalam Prespektif Sejarah dan Ajaran, Surabaya: Khalista, 2007.

Notoatmodjo. Pengembangan Sumber Daya Manusia. Jakarta: Rineka Cipta. 2003

Olofsson \& Lindberg. Whatever Happened do The Social Dimension Aspect of learning in a Distance-based Teacher, 2006.

Said Aqil Siradj, Ahlussunnah Waljamaah dalam Lintas Sejarah, Yogyakarta: LKPSM, 1999.

Saondi, \& Suherman. Etika Profesi Keguruan. Bandung: PT Refika Aditama, 2010.

Shahin A \& Samea, M. "developing the models of service quality gaps: A Critical Discussion”. Jurnal Macrothink Institute. Business Management and Strategy. 2010, 1 (1): E2.

Simamora. Panduan Riset Perilaku Konsumen. Jakarta: Gramedia Pustaka Utama. 2004.

Soemarman, T. Maximizing Training. Malang; Diamo. 2010. 